\title{
Influence of DEM resolution on the RUSLE model: Case of abandoned quarries in Settat province (Morocco)
}

\author{
Nabil Aouichaty ${ }^{*}$, Yassine Bouslihim ${ }^{2}$, Said Hilali ${ }^{1}$, Abdeljalil Zouhri $^{3}$, and Yahya Koulali ${ }^{1}$ \\ ${ }^{1}$ Hassan First University of Settat, Faculty of Sciences and Techniques, BNRNE Laboratory, Settat, Morocco \\ ${ }^{2}$ Hassan First University of Settat, BO 473, 26000, Settat, Morocco \\ ${ }^{3}$ Hassan First University of Settat, Faculty of Sciences and Techniques, CAE Laboratory, Settat, Morocco
}

\begin{abstract}
Topographic slope information is one of the critical variables, which governs soil erosion. This topographic slope can be derived from the Digital Elevation Model (DEM). Significant discrepancies are found in the estimation of soil erosion using different DEMs of different resolutions. In the present study, the Revised Universal Soil Loss Equation (RUSLE) was used for soils in the Settat province (Morocco) to assess the risk of water erosion caused by abandoned quarries. The soil erosion rate was divided into five classes to illustrate the erosion rate variability using two DEMs $(30 \mathrm{~m}$ and $90 \mathrm{~m})$. The impact of topography on erosion was determined by calculating the value of the LS factors. In this case, the values obtained vary between 0 - 120.623 for ASTER DEM (30m) and 0 - 10.225 for DEM SRTM (90m). The results also show that most quarries have a soil loss rate that varies between $0 \mathrm{t} / \mathrm{ha} /$ year and $8.1 \mathrm{t} / \mathrm{ha} / \mathrm{year}$ for ASTER DEM $(30 \mathrm{~m})$. However, for DEM SRTM $(90 \mathrm{~m})$, the soil loss rate is zero. This suggests that RUSLE model users should use high-resolution input data for a close representation of reality and capture the maximum results with reasonable accuracy.
\end{abstract}

\section{Introduction}

Water erosion is the main threat to soil degradation in Morocco[1] and causes an annual loss of soil ranging from $5 \mathrm{t} / \mathrm{ha} /$ year to more than $50 \mathrm{t} / \mathrm{ha} /$ year, depending on each region's specific conditions[2,3]. Therefore, previous studies have shown the direct impact of abandoned quarries on mass movements and landslides. This can increase the risk of erosion in vulnerable areas[4,5].

This study aims to i) identify and quantify the erosion rates in Twenty-two abandoned quarries in the province of Settat (central Morocco)[6] using the RUSLE model and ii) study the effect of the resolution of the Digital Elevation Model (DEM) on soil erosion rate by comparing two DEMs at two different resolutions.

\section{Materials and methods}

\subsection{Presentation of RUSLE}

The Revised Universal Soil Loss Equation (RUSLE)[7,8] is an update of the USLE model of Wischmeier \& Smith[9,10]. The RUSLE model estimates the average annual rate of soil loss and establishes the spatial distribution of erosion risks[10]. It's been recognized as the best-suited model for quantifying soil loss and may better guide soil conservation plans to control water erosion[10,11]. The assessment and mapping of erosion require different types of data that reflect the reality on the ground. Among the factors that control this phenomenon are, for example, topography, land use, climate, and soil characteristics.

To achieve this study's objectives, the RUSLE model was applied, following the methodology presented in Figure 1. The soil water erosion risk assessment was applied using the RUSLE model from two DEMs of different resolutions, namely $30 \mathrm{~m}$ and $90 \mathrm{~m}$. A combination of the two DEMs with other factors influencing the erosion phenomenon, such as land use map, soil map, and precipitation data, was also considered.

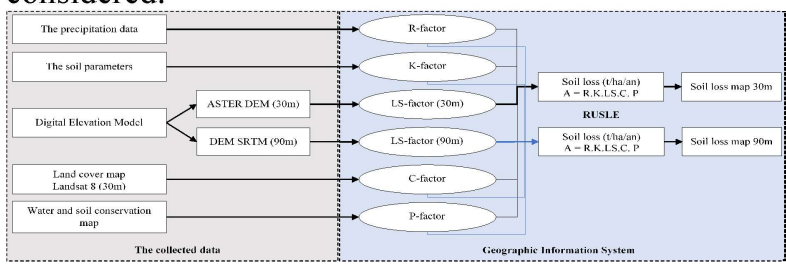

Fig. 1. Descriptive chart of the methodology adopted.

According to the RUSLE model (equation 1), the soil loss (A) is a multiplicative function that takes into account five factors: rainfall erosivity (R), soil erodibility $(\mathrm{K})$, the topographic factor (LS), the vegetation cover factor $(\mathrm{C})$ and erosion control practices factor $(\mathrm{P})[12]$. These different factors were created in the ArcGIS software (version 10.5)[7].

$$
A=R . K . L S . C . P
$$

\footnotetext{
* Corresponding author: aouichaty.nabil@gmail.com
} 


\subsection{The RUSLE factors}

\subsubsection{Rainfall erosivity (R)}

The R-factor depends mainly on climatic data, as precipitation plays a significant role in generating erosion risks and patterns. Precipitation data for 20 years was downloaded from the NASA POWER Data Access Viewer database for 14 stations spread over the entire study area.

The rainfall erosivity map was produced: first by calculating the R-factor (equation 2)[13] for each station, and then creating the erosivity map using the Inverse Distance Weighting (IDW) interpolation method with ArcGIS software (version 10.5)[14-16].

$$
\log R: 1,74 * \log \left(\frac{p_{i}^{2}}{p}\right)+1,29
$$

where $\mathrm{R}$ is rainfall erosivity index (MJ.mm/ha.h.year)[10]. $\mathrm{Pi}$ and $\mathrm{P}$ are the average monthly precipitation $(\mathrm{mm})$ and annual precipitation $(\mathrm{mm})$, respectively[17].

\subsubsection{Soil erodibility (K)}

The K-factor depends mainly on soil texture, organic matter, and permeability[7]. The soil erodibility map of the study area was produced by ArcGIS software (version 10.5), based on the soil characteristics collected from the ISRIC-World Soil Information database. Soil erodibility was determined by the following equation (3) [18-20].

$$
\begin{aligned}
& K_{\text {usle }}=\left[0.2+0.3 \times e^{-0.256 \times m_{s}\left(1-\frac{m_{\text {silt }}}{100}\right)}\right] \times \\
& \left(\frac{m_{\text {silt }}}{m_{C}+m_{\text {silt }}}\right)^{0.3} \times\left[1-\frac{0.25 \times \text { orgC }}{\text { orgC }+e^{3.72-2.95 \times \text { orgC }}}\right] \times[1- \\
& \left.\frac{0.7 \times\left(1-\frac{m_{S}}{100}\right)}{\left(\frac{1-m_{S}}{100}\right)+e^{-5.51+2.95 \times\left(1-\frac{m_{S}}{100}\right)}}\right]
\end{aligned}
$$

Where KUSLE is soil erodibility index (t.ha.h/ha.MJ.mm)[21]; ms, msilt and $\mathrm{mC}$ are the percent sand content, silt content and clay content, respectively; and orgC is the percent organic carbon content of the layer $(\%)[22,23]$.

\subsubsection{The topographic factor (LS)}

The LS factor combines the slope length (L) and the steepness (S)[24]. The LS map was made using the following two DEMs: ASTER DEM 30m and DEM SRTM 90m. Equation 4, developed by Mitasova et al. and Hoffmann et al.[25,26], was applied in this sense using the raster calculator function in ArcGIS software (version 10.5)[27].

$$
\begin{gathered}
\text { LS }=\text { Power }((\text { Flow Acc(FlowDir(DEM)) }) * \\
\text { Resolution) / 22.1,0.4) } * \\
\text { Power (Sin (Slope of degree } * 0.01745) /
\end{gathered}
$$
$0.09,1.4) * 1.4$

Where Flow Acc is Flow Accumulation, and Flow Dir is Flow Direction, there are two functions integrated in the GIS software used in this study.

\subsubsection{The vegetation cover factor $(C)$}

The vegetation cover is the most critical factor for soil protection and slows down soil erosion's extent[7]. In this study, we evaluated the C-factor using Landsat 8 image, which was used for supervised classification to establish the land cover map of the study area (Table 1) [10],

Table 1. Classification of the vegetation cover (Cfactor)[10].

\begin{tabular}{|l|l|}
\hline Classes & C-factor \\
\hline Built-up land & 0.003 \\
\hline Forest & 0.004 \\
\hline Bare land & 1 \\
\hline Water body & 0 \\
\hline Agriculture & 0.4 \\
\hline Uncultivated land & 0.75 \\
\hline
\end{tabular}

\subsubsection{Erosion control practices factor $(P)$}

The erosion control practices are contour cultivation, bench reforestation, and ridging[28]. In our study area, the $\mathrm{P}$-factor value assigned to the whole site was $1[5,10]$, as there are no soil conservation techniques in the province.

\section{Result and discussion}

\subsection{Evaluation of water erosion factors}

\subsubsection{The R-factor}

According to Figure 2, the R-factor values vary from 55 to $73 \mathrm{MJ} . \mathrm{mm} /$ ha.h.year. High values are recorded in the northeast, while low values are recorded in the southwest. This slight difference is due to the altitudinal variations that the province presents from the south to the north and thus the increase in the amount of precipitation recorded from southwest to northeast. This explains the high erosivity of precipitation in most quarries, where the values exceed $60 \mathrm{MJ} . \mathrm{mm} / \mathrm{ha}$.h.year.

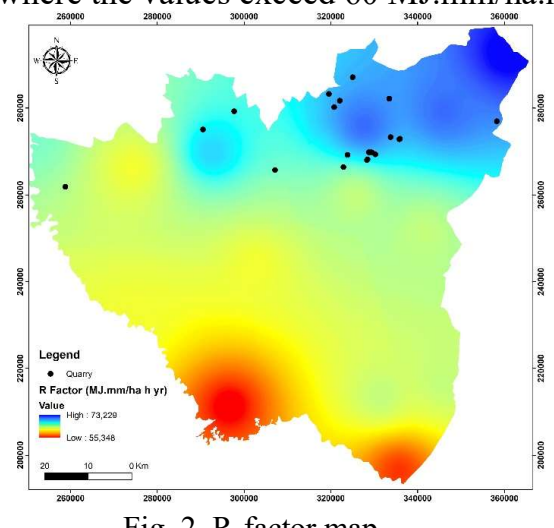

Fig. 2. R-factor map. 


\subsubsection{The K-factor}

The K-factor values vary between 0.035 and 0.053 (Fig.3); this shows that there is a low erodibility rate on the province's soil.

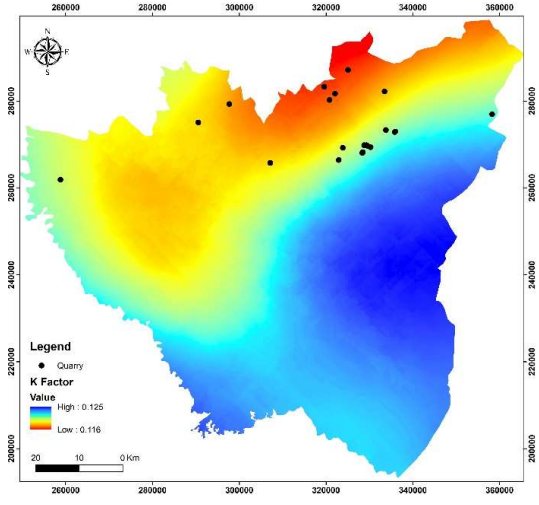

Fig. 3. K-factor map.

\subsubsection{The LS-factor}

The study area has an elevation ranging from $15 \mathrm{~m}$ to $870 \mathrm{~m}$ from west to east [12]. The length and steepness factors significantly influence the soil erosion processes. The application of equation 4 in the province gives values of the topographic factor LS that vary between 0 and 120.623 for ASTER DEM (30m) (Fig. 4) and between 0 and 10.225 for DEM SRTM (90m) (Fig. 5). This difference in LS results is related to the resolution of the DEM.

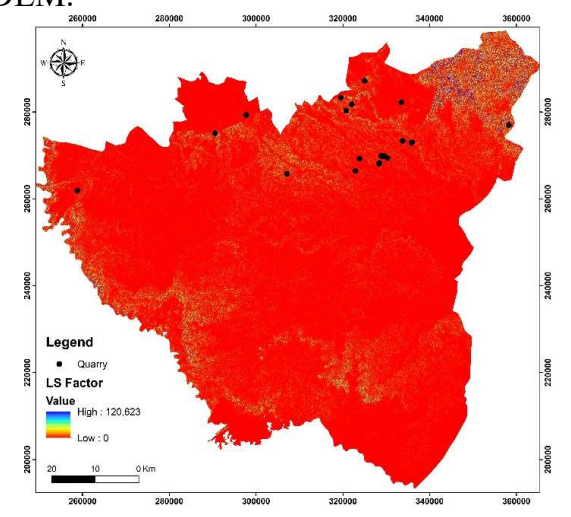

Fig. 4. LS factor map for ASTER DEM (30m).

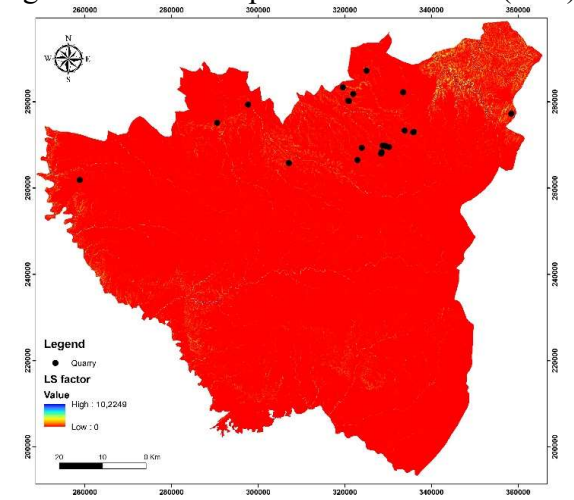

Fig. 5. LS factor map for DEM SRTM (90m).

\subsubsection{The C-factor}

The annual soil loss from agricultural land depends on the type of cultivation. The higher the vegetation cover, the lower the soil erosion[29]. As shown in Figure 6, the quarry is located on bare land according to the vegetation classification in Table 1.

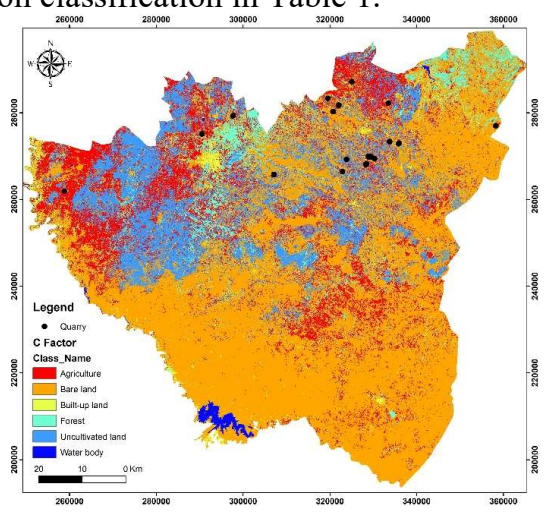

Fig. 6. C-factor map.

\subsection{Evaluation of soil loss}

The evaluation of soil loss in our area ranged from 0 to $282,774 \mathrm{t} / \mathrm{ha} /$ year for DEM $(30 \mathrm{~m})$ and from 0 to 13.79 $\mathrm{t} / \mathrm{ha} /$ year for DEM $(90 \mathrm{~m})$. This assessment was obtained by overlaying the five factors evaluated under ArcGIS software (version 10.5).

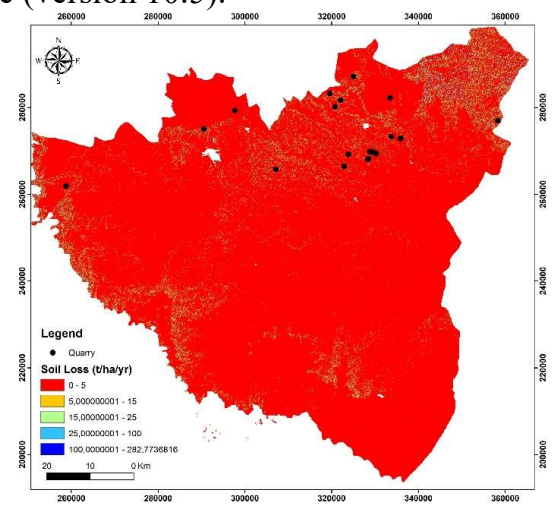

Fig. 7. Resulting soil loss map in $\mathrm{t} / \mathrm{ha} /$ year for ASTER DEM

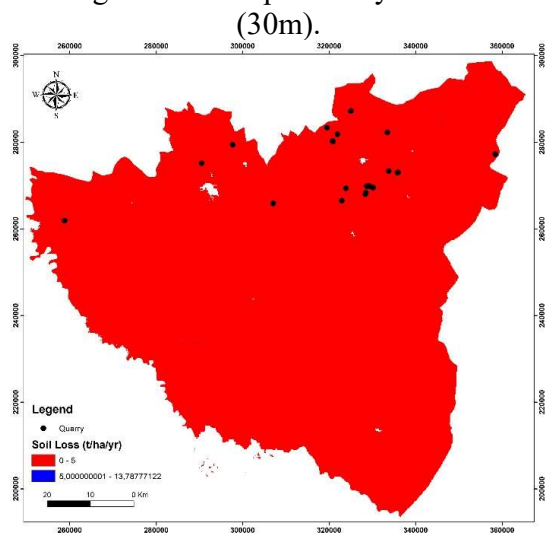

Fig. 8. Resulting soil loss map in $\mathrm{t} / \mathrm{ha} /$ year for DEM SRTM (90m).

According to the classification proposed by[30,31] (Table 2), the results obtained for the abandoned quarries show that the average values vary between 0 and $8.1 \mathrm{t} / \mathrm{ha} /$ year for ASTER DEM (30m) (Fig.7). In contrast, for DEM SRTM $(90 \mathrm{~m})$, there is a low erosion 
risk with a zero-soil loss rate (Fig.8). The analysis of the five factors used in this study shows that the values of the $\mathrm{K}$-factor are very similar throughout the province; thus, the same values were attributed to the $\mathrm{C}$-factor and $\mathrm{P}$-factor for all quarries, the higher values are explained by the high precipitation rate represented by the R-factor and by the topographic conditions characterizing the slopes (LS-factor). These results confirm the effect of the resolution of the input data on the final map; therefore, it is recommended to use high-resolution data to model the ground reality well and especially when one is interested in analyzing the effect of a natural phenomenon such as erosion in small areas such as quarries in the present case.

Table 2. Soil loss classes adapted from Beskow et al.[30].

\begin{tabular}{|l|l|}
\hline Soil loss rate $(\mathrm{t} / \mathrm{ha} /$ year $)$ & Qualitative soil loss class \\
\hline $0-5$ & Slight \\
\hline $5-15$ & Medium \\
\hline $15-25$ & High \\
\hline $25-100$ & Very High \\
\hline$>100$ & Extremely High \\
\hline
\end{tabular}

\section{Conclusion}

There are many advantages to using the RUSLE method in a GIS environment, including many results. This is because it allows for the rational management of many quantitative and qualitative data related to various erosive factors. However, this study reflects the RUSLE soil modeling's inconsistencies based on different DEM resolutions (30m and $90 \mathrm{~m})$. The RUSLE model's use showed that the average value of soil loss rate varies between 0 and $8.1 \mathrm{t} / \mathrm{ha} /$ year for ASTER DEM (30m) and zero for DEM SRTM $(90 \mathrm{~m})$ at the level of the abandoned quarries of Settat province.

This soil loss is due to topographic and rainfall conditions. The present study compares the soil loss of the different DEM resolutions to evaluate the input data's effect on the final results. In short, the finer and more suitable resolution for a better result.

\section{References}

1. A. Ouallali, M. Moukhchane, H. Aassoumi, F. Berrad, I. Dakir, Bull. l'Institut Sci. Rabat, Sect. Sci. la Terre, Genève 65 (2016)

2. Retrieved March 10, 2021, from http://www.eauxetforets.gov.ma/Desertification/ C-E-S/Pages/Erosion-Au-Maroc.aspx

3. A. Benchettouh, L. Kouri, S. Jebari, Arab. J. Geosci. 10, 79 (2017)

4. M. Y. Koca, C. Kincal, Eng. Geol. 75, 49 (2004)

5. M. Taoufik, I. Loukili, H. El Hadi, B. Baghdad, Proc. - 2020 IEEE Int. Conf. Moroccan Geomatics, MORGEO 2020. Institute of Electrical and Electronics Engineers Inc.

6. A. Nabil, K. Yahya, B. Yassine, H. Said, Ecol. Eng. Environ. Technol. 22, 83 (2021)

7. K. G. Renard, G. R. Foster, G. A. Weesies, D. K. McCool, D. C. Yoder, Agric. Handb. 703, 25
(1996)

8. K. Sanogo, B. Zemadim, F. Kizito, (2021)

9. W. H. Wischmeier, D. D. Smith, Predicting rainfall erosion losses: a guide to conservation planning. Department of Agriculture, Science and Education Administration

10. A. El Jazouli, A. Barakat, R. Khellouk, J. Rais, M. El Baghdadi, Remote Sens. Appl. Soc. Environ. 13, 361 (2019)

11. A. A. Millward, J. E. Mersey, Catena 38, 109 (1999)

12. G. Nguyen, J. Broda, J. Grzybowska-Pietras, IOP Conf. Ser. Earth Environ. Sci. (Vol. 221, p. 12128). IOP Publishing

13. A. Rango, H. M. J. Arnoldus, Cah. Tech. la FAO 9, (1987)

14. Y. Ostovari, A. A. Moosavi, H. Mozaffari, H. R. Pourghasemi, Arab. J. Geosci. 14, 1 (2021)

15. L. Bou-Imajjane, M. A. Belfoul, Appl. Environ. Soil Sci. 2020, (2020)

16. J. D. Niyonsenga, M. Mugabowindekwe, C. Mupenzi, Trans. GIS 25, 735 (2021)

17. J. B. Kim, P. Saunders, J. T. Finn, Environ. Manage. 36, 872 (2005)

18. S. L. Neitsch, J. G. Arnold, J. R. Kiniry, J. R. Williams, (2000)

19. A. Pandey, V. M. Chowdary, B. C. Mal, Water Resour. Manag. 21, 729 (2007)

20. J. R. Williams, V. Singh, Water Resour. Publ. Highl. Ranch, Color. 909 (1995)

21. E. H. Erdogan, G. Erpul, İ. Bayramin, Environ. Monit. Assess. 131, 153 (2007)

22. P. Koirala, S. Thakuri, S. Joshi, R. Chauhan, Geosciences 9, 147 (2019)

23. M. K. Kolli, C. Opp, M. Groll, Environ. Earth Sci. 80, 1 (2021)

24. K. Ghosal, S. Das Bhattacharya, J. Indian Soc. Remote Sens. 48, 689 (2020)

25. A. Hoffmann, M. A. da Silva, M. L. Naves Silva, N. Curi, G. Klinke, D. A. F. de Freitas, Soil Process. Curr. Trends Qual. Assess. InTechOpen Limited London

26. H. Mitasova, J. Hofierka, M. Zlocha, L. R. Iverson, Int. J. Geogr. Inf. Syst. 10, 629 (1996)

27. A. W. Kamamia, C. Vogel, H. M. Mwangi, K. Feger, J. Sang, S. Julich, (2021)

28. E. Roose, Land husbandry: components and strategy (Vol. 70). FAO Rome

29. S. Maury, M. Gholkar, A. Jadhav, N. Rane, Environ. Earth Sci. 78, 144 (2019)

30. S. Beskow, C. R. Mello, L. D. Norton, N. Curi, M. R. Viola, J. C. Avanzi, Catena 79, 49 (2009)

31. D. Olivetti, R. L. Mincato, J. E. B. Ayer, M. L. N. Silva, N. Curi, Ciência e Agrotecnologia 39, 58 (2015) 